\title{
ИССЛЕДОВАНИЕ НЕОКОЛЛАГЕНОГЕНЕЗА В ОБЛАСТИ ИМПЛАНТАЦИИ ЭНДОПРОТЕЗА «PARIETENE PROGRIP» В ЗАВИСИМОСТИ ОТ ИСПОЛЬЗОВАНИЯ ПРЕПАРАТА «СОЛКОСЕРИЛ»
}

\author{
(С Лазаренко В.А. ${ }^{2}$, Иванов С.В. ${ }^{1}$, Иванов И.С. ${ }^{1}$, Парфенов И.П. ${ }^{6}$, Горяинова Г.Н. ${ }^{3}$, Пашина Н.Р. ${ }^{5}$, \\ Никишина Е.И. ${ }^{5}$, Иванов А.В. ${ }^{4}$ Объедков Е.Г.
}

\begin{abstract}
${ }^{1}$ Кафедра хирургических болезней № $1,{ }^{2}$ кафедра хирургических болезней ФПО, ${ }^{3}$ кафедра патологической анатомии, ${ }^{4}$ кафедра гистологии, эмбриологии, цитологии Курского государственного медицинского университета, Курск; ${ }^{5}$ кафедра гистологии, цитологии и эмбриологии Первого Московского государственного медицинского университета имени И.М. Сеченова, Москва; ${ }^{6}$ Городская клиническая больница им. С.П. Боткина, Москва E-mail: ivanov.is@mail.ru
\end{abstract}

В настоящее время лечение подавляющего числа больных с грыжами живота предусматривает только хирургическое лечение - эндопротезирование. Разработка и внедрение новых материалов для пластики непременно положительно сказывается на лечении больных с грыжами передней брюшной стенки, но не решает вопроса дисплазии соединительнотканных структур. Работа выполнено на 120 мышах (2 группы, по 60 особей). Оценка состояния соединительной ткани в парапротезной области производилась путем подсчета коллагеновых волокон I и III типов по результатам поляризационной микроскопии. Установлено коллагеностимулирующее действие препарата «Солкосерил». В сочетании с полурассасывающимся эндопротезом, «Солкосерил» достоверно ускоряет созревание парапротезных соединительнотканных структур и способствует увеличению их плотности.

Ключевые слова: «Солкосерил», вентральная грыжа, коллаген, эндопротезирование, «Parietene ProGrip».

\section{STUDY OF NEOCOLLAGENESIS IN THE AREA OF «PARIETENE PROGRIP» ENDOPROSTHESIS IMPLANTATION AS A RESULT OF USING SOLCOSERYL Lazarenko V.A. ${ }^{2}$, Ivanov S.V. ${ }^{l}$, Ivanov I.S. ${ }^{l}$, Parfenov I.P. ${ }^{5}$, Goryainova G.N. ${ }^{3}$, Pashina N.R. ${ }^{5}$, Nikishina E.I. ${ }^{5}$, Ivanov A.V. ${ }^{4}$, Ob'edkov E.G. ${ }^{1}$}

${ }^{1}$ Department of Surgical Diseases N 1, ${ }^{2}$ Department of Surgical Diseases of FPE, ${ }^{3}$ Department of Pathological Anatomy, ${ }^{4}$ Department of Histology, Embryology, Cytology of Kursk State Medical University, Kursk; ${ }^{5}$ Histology,

Department of Cytology and Embryology of I.M. Sechenov First Moscow State Medical University, Moscow;

${ }^{6}$ S.P. Botkin Municipal Clinical Hospital, Moscow

Nowadays treating patients with hernia disease is a purely surgical question. Development and introduction of new materials for the replacement will certainly have a positive impact on the treatment of patients with hernias of the anterior abdominal wall, but do not solve the problem of dysplasia of connective tissue structures. The experimental study included 120 white laboratory mice. Animals were divided into two groups, 60 animals each. The division into two groups was due to using "Solkoseril". The effectiveness of "Solkoseril" on the formation of connective tissue was evaluated by counting the I and III types collagen in a paraprosthesis region, determining their ratio and density of connective tissue structures by using polarizing microscopy. The study revealed the collagen stimulating effect of "Solkoseril". The combination of a half-absorbable material for replacement therapy with "Solkoseril" allows to obtain maximum results, both for maturation of connective tissue structures and significant $(\mathrm{p} \leq 0.05)$ increase in their density.

Keywords: "Solkoseril", ventral hernia, collagen, endoprosthesis, "Parietene ProGrip".

В настоящее время лечение подавляющего числа больных с грыжами живота предусматривает только хирургический принцип лечения. Разработка и внедрение новых материалов для эндопротезирования непременно положительно сказывается на лечении больных с грыжами передней брюшной стенки, но не решает вопроса дисплазии соединительнотканных структур [3, 10]. Значительную роль в уменьшении воспалительной реакции в области имплантации эндопротеза играют процессы формирования зрелой соединительной ткани [3, 7, 11]. Максимального эффекта от проводимого лечения можно добиться путем влияния на процесс коллагеногенеза, что подразумевает под собой увелечение количества зрелого коллагена I типа $[12,13]$.

Изучение структуры соединительнотканных образований у больных с грыжевой болезнью выявило четкую взаимосвязь между данной патологией и различными типами коллагенозов $[2,6]$. Исследования по изучению структуры соединительной ткани были обусловлены как сохраняющимися рецидивами после выполненных пластик передней брюшной стенки по поводу грыжевой болезни, так и формированием грыж после проведенных операций на органах брюшной полости $[1,4,9]$. 
Совершенствование материалов для эндопротезирования, улучшение их биосовместимости не могло не привести к внедрению новых материалов в клиническую практику [5]. Одним из таких инновационных материалов является полурассасывающийся самофиксирующийся эндопротез с микрокрючками из полимолочной кислоты «Parietene ProGrip». Широкое внедрение данного эндопротеза позволило в значительной степени снизить частоту рецидивов и осложнений при эндопротезировании передней брюшной стенки, но полностью не решило данную проблему [8].

\section{МАТЕРИАЛЫ И МЕТОДЫ ИССЛЕДОВАНИЯ}

Экспериментальное исследование было выполнено на 120 особях белых лабораторных мышей самцов со средним весом 25-30 г. Выбор животных определен проблемной комиссией и согласован с этическим комитетом. Все животные проходили карантин на базе ФГБОУ ВО «Курский государственный медицинский университет» Минздрава России. В начале эксперимента животные были поделены на две группы, по 60 особей каждая. Деление на группы было обусловлено применением препарата. Всем животных имплантировался эндопротез «Parietene ProGrip» (компания Covidien, Франция). Деление на группы было обусловлено использованием препарата «Солкосерил», его получали животные, находившиеся во второй группе.

Оперативные вмешательства выполняли в строго асептических условиях с использованием эфирного наркоза. Вначале производился разрез кожи на передней брюшной стенке длиной $1 \mathrm{~cm}$, затем формировали «пространство», размер которого соответствовал эндопротезу (размером 0,5 x 1,0 см) без последующей его фиксации. Ушивание раны производили непрерывным швом. Животным второй группы внутрибрюшинно вводился $50 \%$ раствор препарата «Солкосерил» в объеме 0,1 мл. Интраоперационно $50 \%$ раствором препарата «Солкосерил» орошался эндопротез, в дальнейшем раствор вводился внутрибрюшинно по 0,1 мл, с помощью инсулинового шприца. Введение препарата производилось через день в течение 90 суток. Животные выводились из эксперимента путем декапитации под эфирным наркозом на 7, 10, 30, 60, 90-е сутки. Данные сроки являются оптимальными с точки зрения естественной регенерации соединительной ткани.

Для получения гистологических препаратов брали участок передней брюшной стенки размером $1,0 \times 1,5$ см вместе с эндопротезом, после чего его фиксировали в $10 \%$ растворе нейтрального формалина. Затем фрагменты брюшной стенки заключали в парафиновые блоки, из которых получали срезы толщиной 7-10 мкм. Полученные срезы помещали на предметные стекла и окрашивали пикросириусом красным (Sirius Red) по стандартной методике. Препараты исследовали на поляризационном микроскопе Altami Polar 2 в поляризационном свете при объективах х10, х25, $\mathrm{x} 40$.

Анализ соотношения типов коллагена в соединительной ткани вокруг эндопротеза проводили по цветовой гамме, индивидуальной для каждого типа. Для определения соотношения коллагенов I и III типов использовали программный комплекс Altami Studio 3.0 и ImageJPRO 1,47. Для изучения плотности соединительной ткани вычисляли концентрацию пикселей на дюйм при помощи графического редактора. Для оценки коллагеностимулирующего эффекта препарата «Солкосерил» и оценки толщины парапротезной капсулы вокруг нитей использовали формулу для расчета толщины парапротезной капсулы:

$$
\mathrm{X}=\frac{92 * \mathrm{~b}}{\mathrm{a}} \text {---- }
$$

где $\mathrm{x}$ - толщина капсулы в мкм; 92 - диаметр нити эндопротеза «Parietene ProGrip» в мкм; a - диаметр нити эндопротеза в пикселях; $\mathrm{b}$ - толщина капсулы в пикселях.

Учитывая отсутствие признаков нормальности распределения полученных данных, обнаруженное при анализе показателей описательной статистики, в качестве основной методики определения уровня статистической значимости отличий было использовано определение границ доверительного интервала (t) при допустимом для экспериментальных медико-биологических исследований in vivo уровне $\mathrm{P} \leq 0,05$.

Вычисления значений t выполнялись с помощью статистических функций аналитического пакета приложения Excel Office 2010, лицензией на право использования которой обладает Курский государственный медицинский университет.

\section{РЕЗУЛЬТАТЫ ИССЛЕДОВАНИЯ И ИХ ОБСУЖДЕНИЕ}

Оценка эффективности влияния препарата «Солкосерил» на процесс формирования соединительной ткани в нашем экспериментальном исследовании производилась путем подсчета коллагеновых волокон I и III типов в парапротезной области, определения их соотношения и плотности соединительнотканных структур. Особое значение нами придавалось изучению структуры соединительнотканной капсулы. Коллагеностиму- 
лирующее влияние препарата «Солкосерил» оценивалось в эксперименте: лабораторным животным имплантировали эндопротез «Parietene ProGrip». Данные, полученные на различных сроках исследования, представлены в табл 1.

Микрофотографии, полученные во время поляризационной микроскопии, и их дальнейший анализ в специальном графическом редакторе помогли установить плотность соединительнотканных структур в области эндопротезирования в группах исследуемых животных. Полученные данные представлены на рис. 1 .

Размер капсулы, сформированной вокруг нитей эндопротеза, играет определяющую роль только в том случае, если соединительнотканные волокна, которыми она представлена, имеют достаточную зрелость и плотность. На представленном ниже рис. 2 указаны размеры капсулы $(\mathrm{M} \pm \mathrm{t})$ вокруг нитей эндопротеза при имплантации эндопротеза «Parietene ProGrip».

При изучении соединительнотканных структур передней брюшной стенки в проходящем поляризационном свете у исследуемых животных установлена зависимость увеличения количества коллагена I типа по отношению к коллагену III типа, впервые проявляющаяся на сроке 30-х суток и в большей степени выраженная в группе животных, получавших препарат «Солкосерил».

Таблица 1

Содержание коллагена I и III типов и их соотношение в парапротезной области при имплантации эндопротеза «Рarietene Progrip» в зависимости от применения препарата «Солкосерил»

\begin{tabular}{|l|c|c|c|c|}
\hline $\begin{array}{c}\text { Срок эксперимента / } \\
\text { введение препарата }\end{array}$ & $\begin{array}{c}\text { I тип } \\
\text { коллагена (\%) }\end{array}$ & $\begin{array}{c}\text { III тип } \\
\text { коллаген (\%) }\end{array}$ & $\mathrm{m}$ & $\begin{array}{c}\text { Соотношение INIII } \\
\text { типов коллагена }\end{array}$ \\
\hline 7 сутки & 47,64 & 52,36 & 0,93 & 0,91 \\
\hline 7 сутки + «Солкосерил» & 49,73 & 50,27 & 1,01 & 0,99 \\
\hline 10 сутки & 48,05 & 51,95 & 1,03 & 0,92 \\
\hline 10 сутки + «Солкосерил» & 51,27 & 48,73 & 0,97 & 1,05 \\
\hline 30 сутки & $57,39^{\mathrm{ab}}$ & $42,61^{\mathrm{ab}}$ & 1,62 & 1,35 \\
\hline 30 сутки + «Слкосерил» & $61,51^{\mathrm{ab}}$ & $38,49^{\mathrm{ab}}$ & 1,45 & 1,59 \\
\hline 60 сутки & $68,56^{\mathrm{ab}}$ & $31,44^{\mathrm{ab}}$ & 2,04 & 2,18 \\
\hline 60 сутки + «Солкосерил» & $74,38^{\mathrm{ab}}$ & $25,62^{\mathrm{ab}}$ & 2,33 & 2,9 \\
\hline 90 сутки & $70,91^{\mathrm{ab}}$ & $29,09^{\mathrm{ab}}$ & 2,32 & 2,43 \\
\hline 90 сутки + «Солкосерил» & $81,65^{\mathrm{ab}}$ & $18,35^{\mathrm{ab}}$ & 2,48 & 4,45 \\
\hline
\end{tabular}

Примечание: a - p $\leq 0,05$ при сравнении с аналогичным сроком в зависимости от применения препарата «Солкосерил», $\mathrm{b}-\mathrm{p} \leq 0,05$ при сравнении с предыдущим сроком одного типа коллагена.

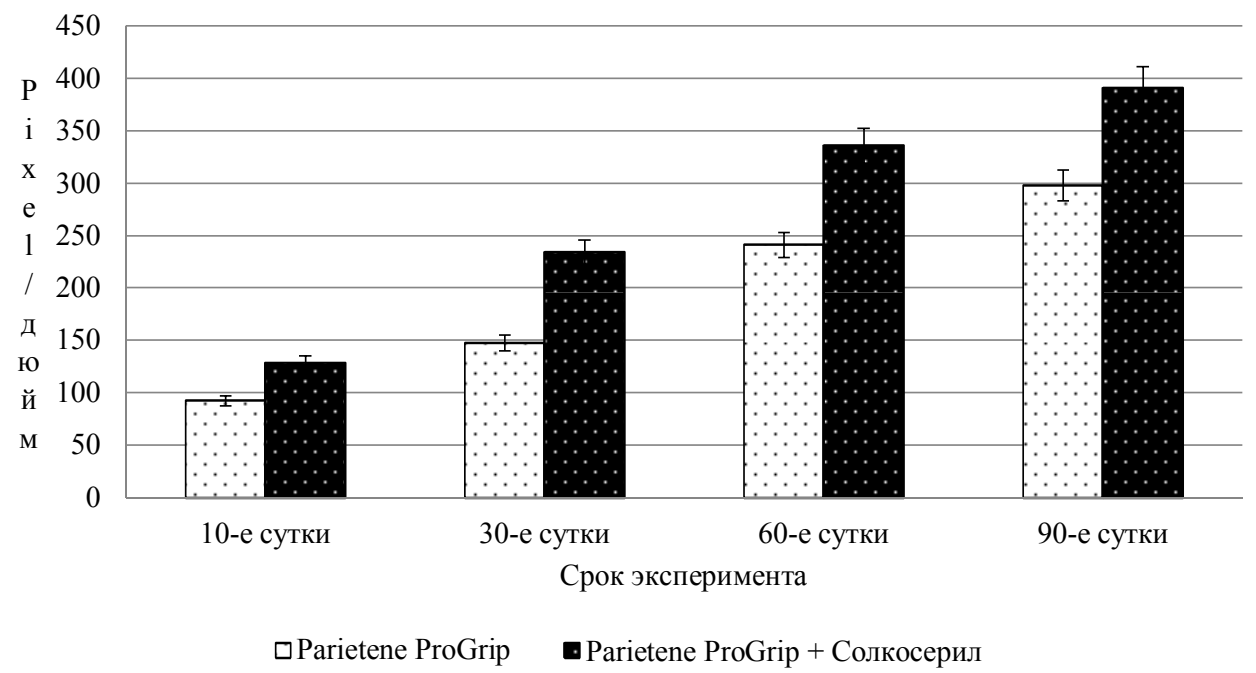

Рис. 1. Плотность коллагеновых волокон в зависимости от введения препарата «Солкосерил».

Примечание: $\mathrm{p} \leq 0,05$ при сравнении плотности соединительной ткани на различных сроках эксперимента в зависимости от применения препарата «Солкосерил». 


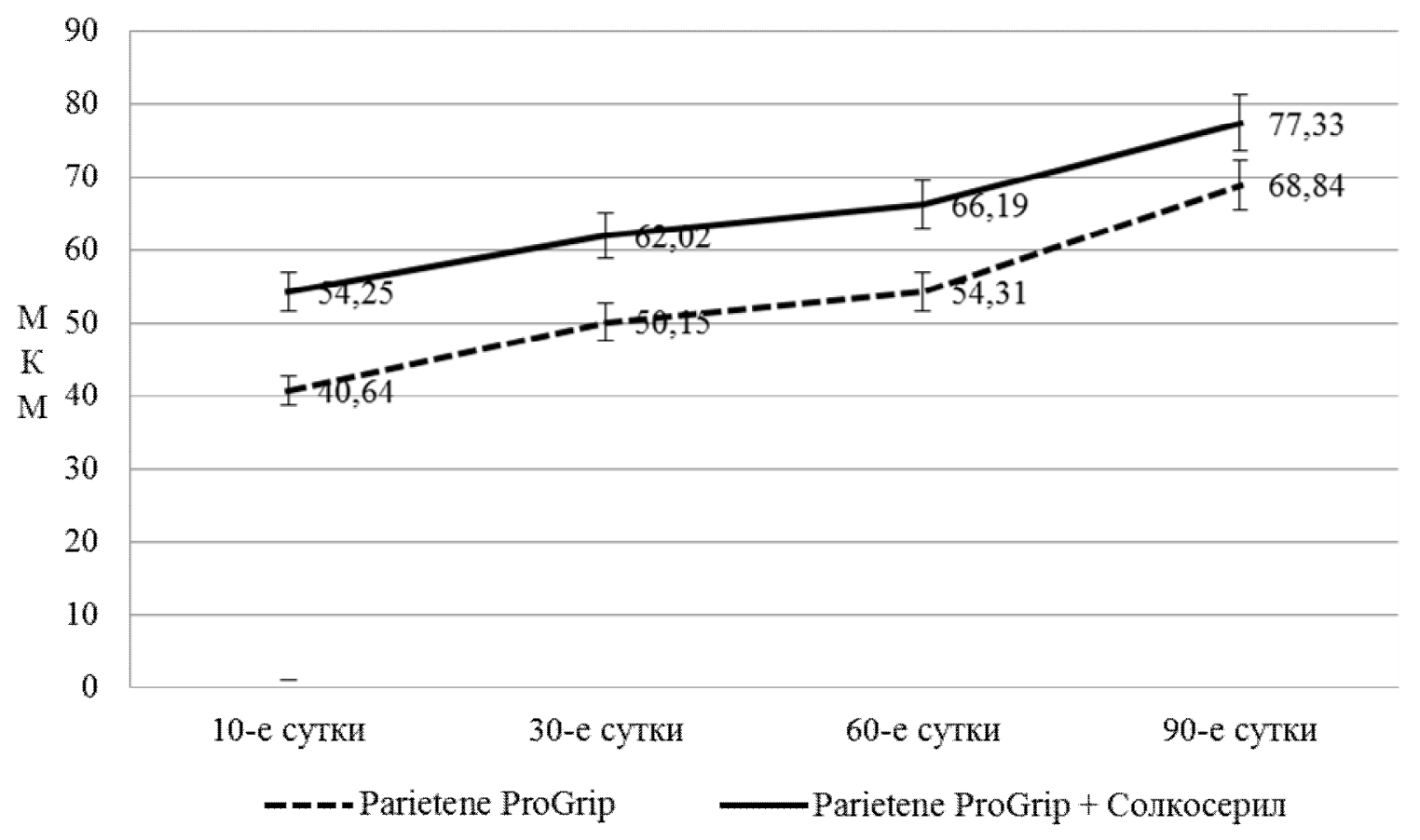

Рис. 2. Размер капсулы (мкм) вокруг нитей эндопротеза в зависимости от применения препарата «Солкосерил».

Примечание: $\mathrm{p} \leq 0,05$ при сравнении толщины капсулы на различных сроках эксперимента.

Процентное содержание коллагеновых волокон I и III типов и их соотношение на 7-е и 10 -е сутки исследования, независимо от использования препарата «Солкосерил», не претерпевает значительных изменений, что характерно для начала процесса коллагеногенеза, вызванного повреждением соединительнотканных структур во время имплантации эндопротеза.

На 10-е сутки экспериментального исследования, независимо от введения препарата, не удается выявить достоверных отличий в строении соединительнотканных образований. Изменение соотношения коллагена I и III типов не претерпевает достоверных изменений в сторону какого-либо из них $(0,92 ; 1,05)$. Соединительнотканная капсула вокруг нитей эндопротеза только начинает формирововаться и не визуализируется на всем протяжении. Коллагеновые волокна на данном сроке исследования не упорядочены. Обращает на себя внимание большое количество разрывов и разволокнений соединительнотканных волокон, что также указывает на низкую плотность соединительной ткани.

Первые качественные структурные изменения в области имплантации эндопротеза выявляются на 30-е сутки эксперимента. При исследовании коллагенового состава соединительной ткани в области имплантации эндопротеза отмечается достоверное $\quad(\mathrm{p} \leq 0,05)$ увеличение волокон коллагена, имеющих красный спектр свечения в поляризационном свете $(57,39 \%$; $61,51 \%)$, что указывает на усиление процесса коллагенеза по сравнению с предыдущими сроками эксперимента. Данная зависимость наиболее выражена в группе животных, получавших препарат (рис. 3). Отмечается упорядоченность коллагеновых волокон на данном сроке исследования, что также отражается на плотности соединительной ткани в области эндопротезирования (147,3 pixel/дюйм; 234,2 pixel/дюйм). Соединительнотканная капсула имеет четкие границы, визуализируется на всем протяжении нитей эндопротеза. В группе животных, получающх препарат «Солкосерил», структурные качества парапротезной капсулы достоверно выше $(\mathrm{p} \leq 0,05)$ по сравнению с группой животных, не получавших препарат, что наглядно продемонстрировано на рис. 3.

На 60-е сутки эксперимента в двух группах животных вокруг нитей эндопротеза отмечается полностью сформировавшаяся капсула. Качество парапротезной капсулы в группе животных, получавших препарат «Солкосерил», выше по сравнению с группой животных, его не получавших. Это в первую очередь проявляется достоверно $(\mathrm{p} \leq 0,05)$ более высокой плотностью соединительной ткани $(335,7 \mathrm{pixel} /$ дюйм к $241,1 \mathrm{pixel} /$ дюйм). Коллагеновый состав соединительной ткани в области эндопротезирования также претерпевает значительные качественные изменения (рис. 4). В группе животных, получавших препарат «Солкосерил», количество коллагена I типа составляет 74,38\%, что достоверно выше $(\mathrm{p} \leq 0,05)$ его значения в сравнении с группой животных, не получавших препарат $(68,56 \%)$. 


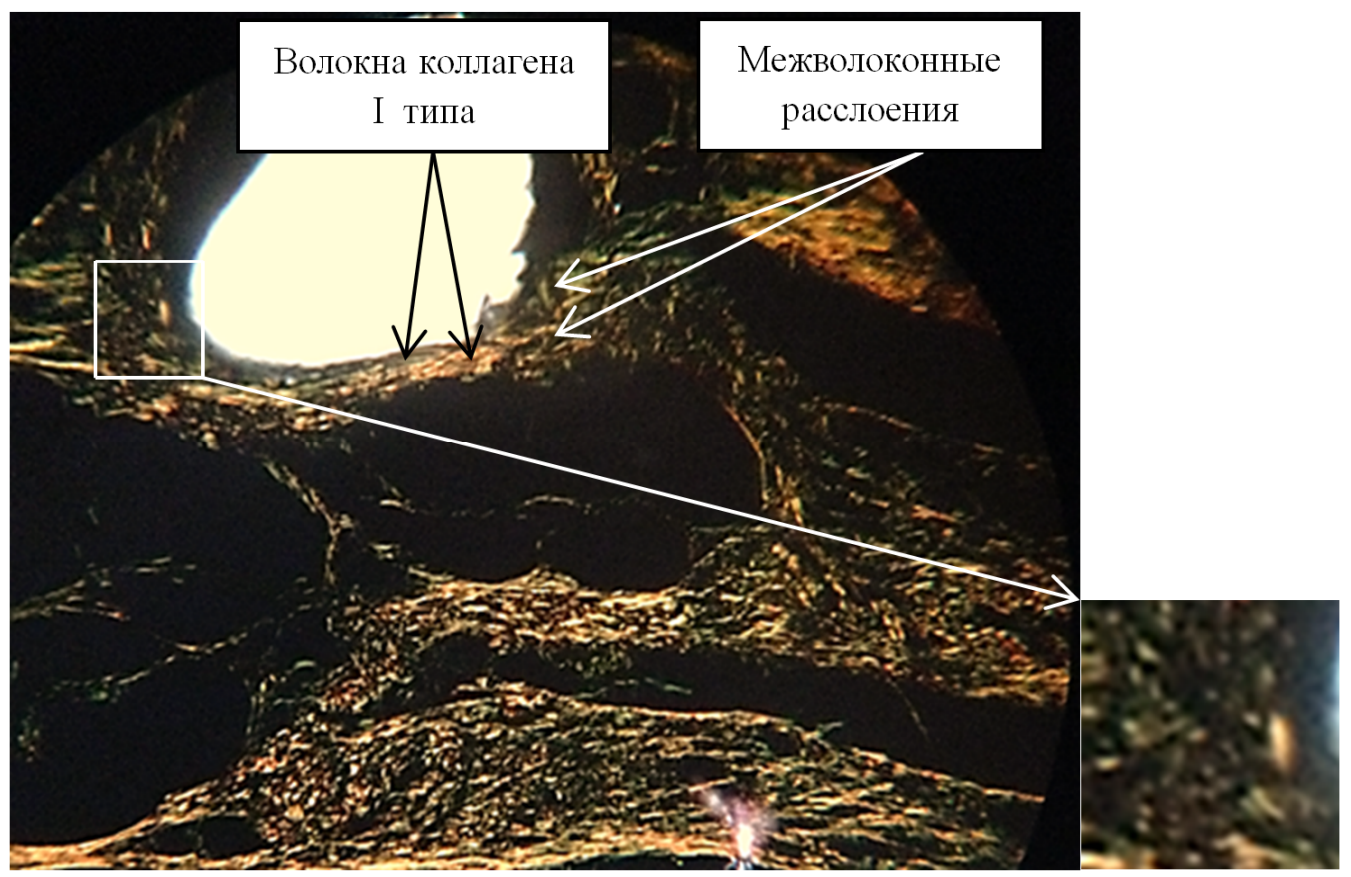

Рис. 3. Микроскопическая картина в области имплантации эндопротеза, 30-е сутки эксперимента (с применение препарата «Солкосерил»). Поляризационная микроскопия. Окраска Sirius Red. X250.

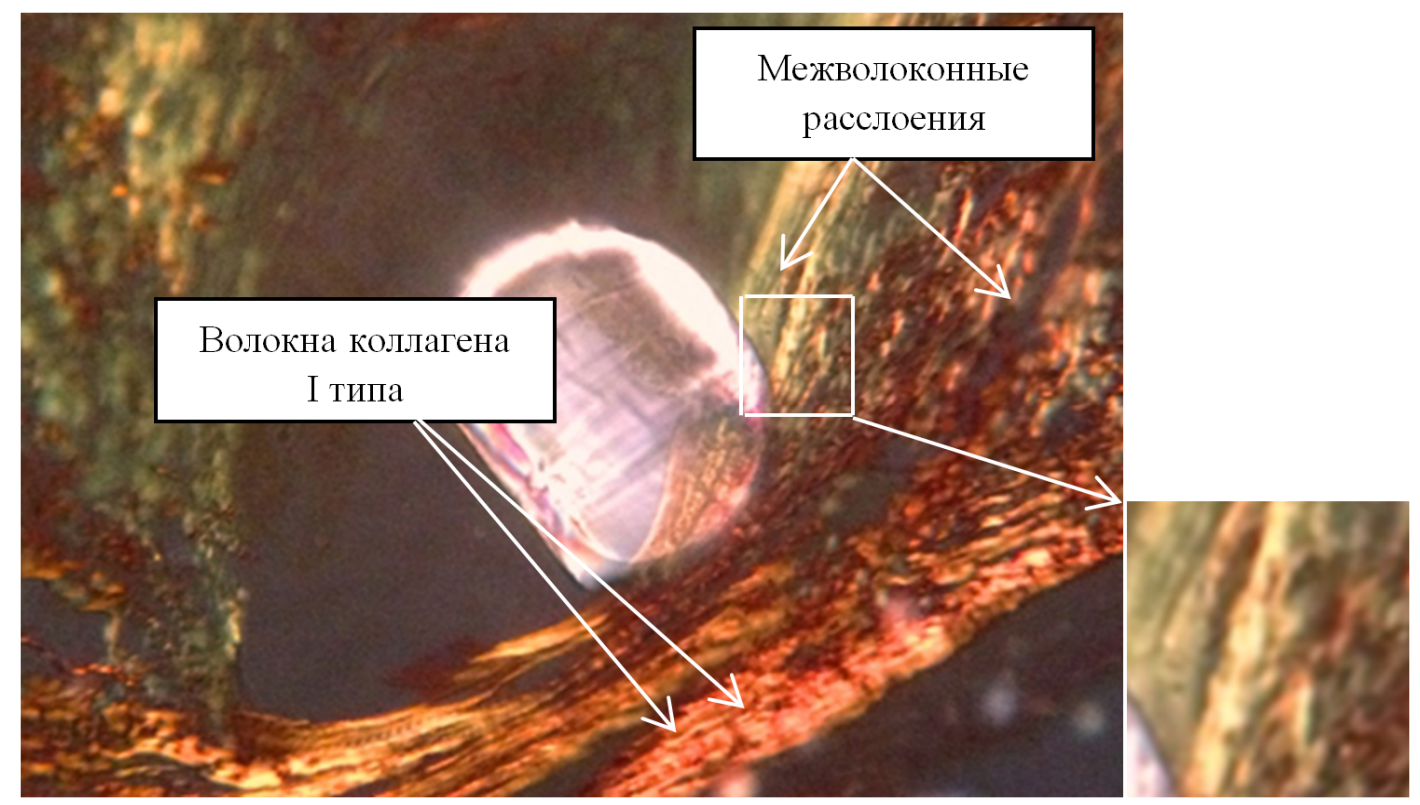

Рис. 4. Микроскопическая картина в области имплантации (с применением препарата «Солкосерил»). Поляризационная микроскопия. Окраска Sirius Red. X400.

Стоит отметить выявление тенденции к ускорению процесса коллагеногенеза в группе животных, получавших «Солкосерил». Это прежде всего видно при анализе соотношения коллагена в двух исследуемых группах по табл. 1.

90-е сутки экспериментального исследования характеризуются наилучшими качественными структурными изменениями как соединительной ткани в области имплантации эндопротеза, так и качеством парапротезной капсулы. Соотношение коллагена I и III типа в группе животных, получающих препарат «Солкосерил», составило
4,45 , что достоверно выше $(\mathrm{p} \leq 0,05)$ в сравнении с группой животных, не получающих препарат,2,43. Коллагеновые волокна I типа в группе животных, получающих препарат, расположены максимально компактно по отношению друг к другу, что объясняет максимальные значения плотности соединительной ткани $391,2 \mathrm{pixel} /$ дюйм $\quad(\mathrm{p} \leq 0,05)$. Парапротезная капсула в обеих группах животных полностью сформирована, представлена преимущественно волокнами коллагена I типа, характеризующими зрелость соединительнотканной капсулы (рис. 5). 


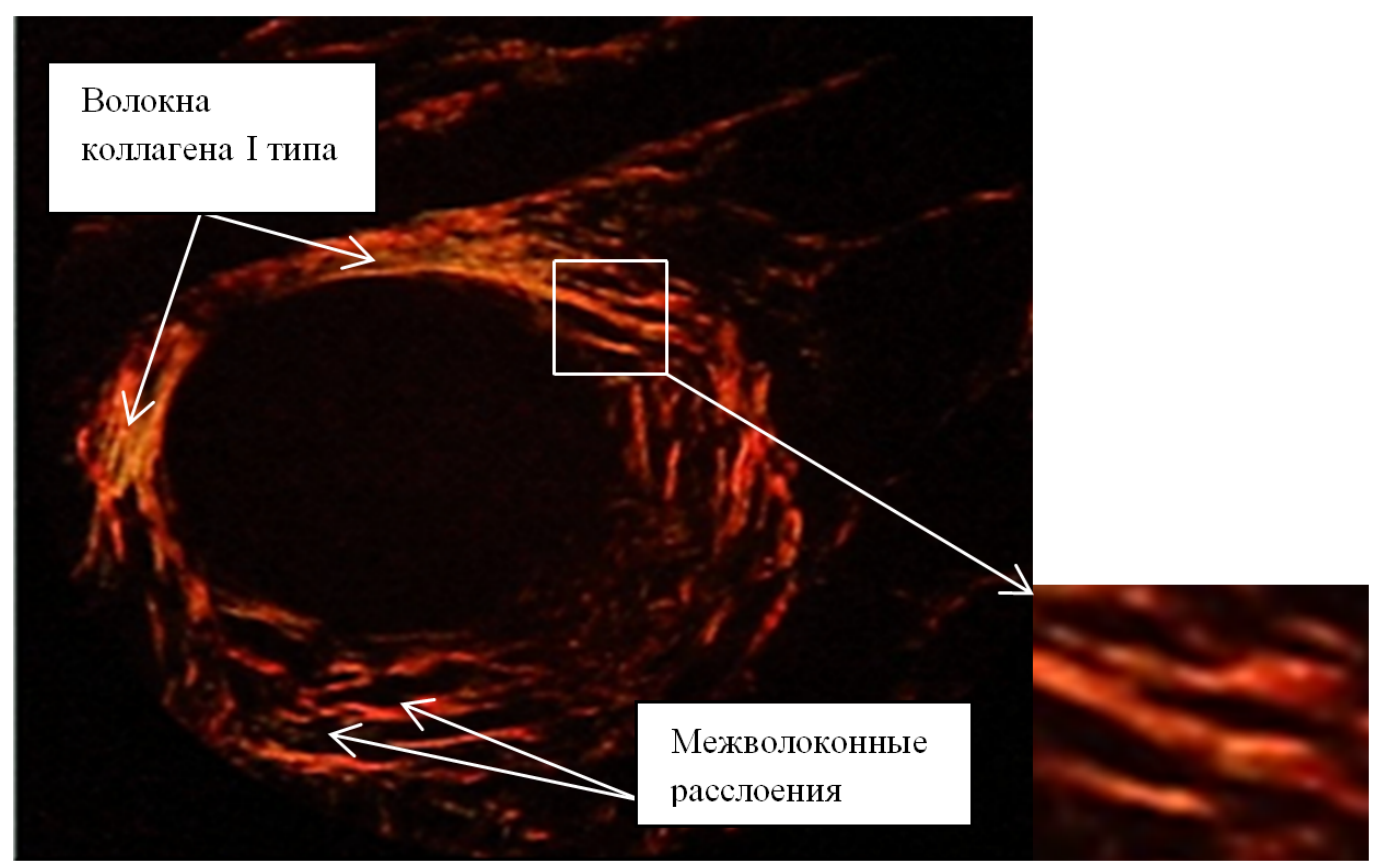

Рис. 5. Микроскопическая картина в области имплантации эндопротеза (с применением препарата «Солкосерил»). Поляризационная микроскопия. Окраска Sirius Red. X400.

Таким образом, несмотря на отсутствие эффекта от применения «Солкосерила» на раних сроках экспериментального исследования, с 30-х суток отмечено увеличение количества коллагена I типа, достоверно большее $(\mathrm{p} \leq 0,05)$ у животных, получавших препарат.

Данная зависимость не только сохраняется на более поздних сроках, но и имеет тенденцию к увеличению соотношения коллагена I и III типа, достигая своего максимума к 90-м суткам исследования. Особое значение имеет формирование соединительнотканной капсулы вокруг нитей эндопротеза. Компактность расположения волокон, превалирование волокон коллагена I типа в парапротезной капсуле делают ее более прочной. Такая тенденция наиболее ярко прослеживается в группе животных, получавших препарат «Солкосерил». Опираясь на результаты, полученные в ходе экспериментального исследования, справедливо говорить о наличии коллагеностимулирующего действия препарата «Солкосерил». Сочетание полурассасывающего материала для эндопротезирования с терапией препаратом «Солкосерил» позволяет получать максимальный результат, как для созревания соединтельно-тканных структур, так и для достоверно $(\mathrm{p} \leq 0,05)$ большего увеличения их плотности.

\section{ЛИТЕРАТУРА}

1. Белоконев В.И., Федорина Т.А., Ковалева З.В., Пушкии С.Ю., Нагапетян С.В., Супильников А.А. Выбор операционного доступа при вентральной грыже // Патогенез и хирургическое лечение послеоперационных вентральных грыж. - Самара: Перспектива, 2005. - С. 135-141.
2. Горпинич А.Б., Свиридов К.Н., Хорошилова И.И., Семин А.С. Результаты лечения больных с послеоперационной вентральной грыжей // Электронный научно-образовательный вестник Здоровье и образование в XXI веке. - 2012. - Т. 14, № 6. - С. 81-82.

3. Иванов С.В., Иванов И.С., Цуканов А.В., Гафаров Г.Н., Объедков Е.Г. Влияние витамина С на динамику соотношения коллагена I и III типов в области имплантации герниопротеза у мышей // Цитология. - 2016. - Т. 58, № 9. - С. 714-719.

4. Пономарева Ю.В., Белоконев В.И., Волова Л.Т., Гуляев М.Г. Морфологические основы причин рецидивов у больных с послеоперационной вентральной грыжей // Фундаментальные исследования. - 2013. - № 9. - С. 263-266.

5. Суковатых Б.С., Валуйская Н.М., Пашков В.М., Алименко О.В., Григорьян А.Ю. Показания и выбор технологии протезирования брюшной стенки для профилактики и лечения послеоперационных вентральных грыж // Бюллетень сибирской медицины. - 2016. - Т. 15, № 1. - С. 89-97.

6. Лазаренко В.А., Иванов И.С., Цуканов А.В., Иванов А.В., Горяинова Г.Н., Объедков Е.Г., Тарабрин Д.В., Гафаров Г.Н. Архитектоника коллагеновых волокон в коже и апоневрозе у больных с вентральными грыжами и без грыжевой болезни // Курский научно-практический вестник «Человек и его здоровье». - 2014. - № 2. C. 41-45.

7. Магакян Ю.А., Каралян З.А., Каралова Е.М., Аброян Л.О., Акопян Л.А., Гаспарян М.Г., Джагаипанян Н.Г., Семерджян 3.Б., ТерПогосян 3.P. Влияние Солкосерила на популяционные и клеточные параметры культур HELA и RD // Цитология. - 2010. - Т. 52, № 2. C. 126-130. 
8. Меджидов Р.Т., Абдулмуслимов Х.М., Койчуев Р.А., Исаев У.З. Вариант «ненатяжной» герниопластики при средних и больших послеоперационных вентральных грыжах // Вестник новых медицинских технологий. -2008. - Т. 15, № 1. - С. 110-111.

9. Broderick G., McIntyre J., Noury M., Strom H.M., Psoinos C., Christakas A., Billiar K., Hurwitz Z.M., Lalikos J.F., Ignotz R.A., Dunn R.M. Dermal collagen matrices for ventral hernia repair:comparative analysis in a rat model // Hernia. - 2012. - Vol. 16, N 3. P. 333-343. - doi: 10.1007/s10029-011-0891-0.

10. Junge K., Klinge U., Rosch R., Mertens P., Kirch J., Klosterhalfen B., Lynen P., Schumpelick $V$. Decreased collagen type I/III ratio in patients with recurring hernia after implantation of alloplastic prostheses // Langenbecks Arch. Surg. - 2004. - Vol. 389, N 1. P. 17-22.

11. Maude R.J., Buapetch W., Silamut K. A simplified, low-cost method for polarized light microscopy // Am. J. Trop. Med. Hyg. - 2009. - Vol. 81, N 5. P. 782783. - doi: 10.4269/ajtmh.2009.09-0383.

12. Rich L., Whittaker P. Nollagen and picrosirius red staining: a polarized light assessmentof fibrillar hue and spatial distribution // Braz. J. Morphol. Sci. 2005. - Vol. 22. - P. 97-104.

13. Weaver $R$. Rediscovering polarized light microscopy // American Laboratory. - 2003. - Vol. 35. - P. 55-61. 